\title{
PENGARUH PENDERITA PENYAKIT BERBAHAYA, KEMISKINAN, DAN PENGANGGURAN DI INDONESIA TERHADAP PERMINTAAN BPJS KESEHATAN
}

\author{
Ade Faisal Fahroez ${ }^{1}$, Estro Dariatno Sihaloho ${ }^{2}$ \\ 1 Departemen Ilmu Ekonomi Fakultas Ekonomi dan Bisnis Universitas Padjadjaran, Jln. Dipati Ukur No. \\ 35, Bandung, 40132, Jawa Barat, Indonesia \\ 2 Departemen Ilmu Ekonomi Fakultas Ekonomi dan Bisnis Universitas Padjadjaran, Jln. Dipati Ukur No. \\ 35, Bandung, 40132, Jawa Barat, Indonesia \\ adefaisalfahroez@gmail.com
}

\begin{abstract}
Social Security in Indonesia is managed by Badan Penyelenggara Jaminan Kesehatan or BPJS Kesehatan, BPJS Kesehatan is a government agency tasked with managing contributions or funds from the public to ensure their health. In 2017 the number of participants BPJS Kesehatan as many as 176,738,998 people, of which 99,044,288 people, their contributions in the form of premiums paid by the government and the other paid financed by institutions where they work or pay independently. This indicates that as many as $56.1 \%$ of them are considered not able to pay dues independently, and are considered a poor society. Of the many participants BPJS Kesehatan, as much as 1.3\% are people with dangerous diseases (Coronary Heart, TBC, Cancer, and AIDS). The purpose this paper is to find out how big the influence of poverty, unemployment, patients with coronary heart disease, tuberculosis patients, people with AIDS disease, and cancer patients to the number of participants BPJS Kesehatan. The method used in this research is multiple regression method using OLS (ordinary Least Square) model by taking secondary data from related institutions. From the data obtained, it turns out all the mentioned variables have a positive correlation to the increase of health insurance participants through BPJS Kesehatan.
\end{abstract}

Keywords: BPJS Kesehatan; Dangerous Disease;Poor People;Unemployment.

\section{ABSTRAK}

Badan Penyelenggara Jaminan Sosial Kesehatan atau BPJS Kesehatan merupakan lembaga pemerintah yang bertugas untuk mengelola iuran atau dana dari masyarakat, yang mereka pergunakan uttuk menjamin kesehatannya. Pada tahun 2017 jumlah peserta BPJS Kesehatan sebanyak 176.738 .998 orang, dimana sebanyak 99.044 .288 orang, iuran mereka berupa premi dibayarkan oleh pemerintah dan sisanya dibiayai oleh institusi tempat mereka bekerja atau bayar secara mandiri. Hal itu mengindikasikan bahwa sebanyak 56,1\% mereka dianggap belum mampu untuk membayar iuran secara mandiri, dan dianggap sebagai masyarakat yang tergolong miskin. Dari banyaknya peserta BPJS Kesehatan, sebesar $1,3 \%$ merupakan penderita penyakit berbahaya (Jantung Koroner, TBC, Kanker, dan AIDS). Tujuan dari pembuatan paper ini adalah untuk mengetahui seberapa besar pengaruh kemiskinan, pengangguran, penderita penyakit jantung koroner, penderita penyakit TBC, penderita penyakit AIDS, dan penderita penyakit kanker terhadap jumlah peserta BPJS Kesehatan. Metode yang digunakan dalam penelitian ini adalah metode regresi berganda menggunakan model OLS (ordinary Least Square) dengan mengambil data secara sekunder dari instansi-instansi terkait. Dari data yang didapatkan, ternyata semua variabel yang disebutkan memiliki korela si yang positif terhadap bertambahnya peserta jaminan kesehatan melalui BPJS Kesehatan.

Kata Kunci : BPJS Kesehatan;Penduduk Miskin;Pengangguran; Penyakit Berbahaya

\section{PENDAHULUAN}

Kemiskinan dan pengangguran merupakan sebuah fenomena yang sering terdengar dan menjadi permasalahan di setiap negara. Hampir setiap negara memiliki masalah dalam kemiskinan dan pengangguran, terutama di negara-negara yang masih dalam tahap berkembang Todaro, (2011). Kemiskinan dan pengangguran secara langsung atau tidak langsung akan memiliki dampak terhadap tingkat kesehatan masyarakat. Menurut (Atmarita, 2015) jumlah pendapatan yang merupakan determinan dari keadaan seseorang miskin atau tidak akan mempengaruhi tingkat kesehatannya. Hal ini tercermin dalam pengeluaran rumah tangga untuk mengkonsumsi makanan yang mengandung protein, vitamin, dan lainnya. Dalam jangka panjang tentunya tingkat konsumsi tersebut akan berpengaruh terhadap kesehatan individu. Pada tingkat makro, kesehatan yang 
baik merupakan input ${ }^{1}$ penting dalam pertumbuhan ekonomi jangka panjang. Beberapa pengalaman besar membuktikan bahwa berhasilnya tinggal landas ekonomi seperti pertumbuhan ekonomi yang cepat didukung oleh adanya terobosan penting dalam kesehatan masyarakat, pemberantasan penyakit, dan peningkatan gizi Atmawikarta, (2008). Hal ini antara lain terjadi di Inggris selama revolusi Industri, Jepang, dan Amerika Selatan pada awal abad ke-20.

Bukti-bukti makroekonomi menjelaskan bahwa negara-negara dengan kondisi kesehatan yang rendah, menghadapi tantangan yang lebih berat untuk mencapai pertumbuhan ekonomi yang berkelanjutan, jika dibandingkan dengan negara yang lebih baik kesehatannya. Kesehatan yang buruk akan memberikan pengaruh buruk terhadap pertumbuhan ekonomi, hal ini antara lain terjadi di negara-negara sub-Sahara dan negara-negara di Asia Selatan².

Kesehatan yang buruk akan memberikan dampak yang negatif terhadap pertumbuhan ekonomi suatu negara, hal ini antara lain disebabkan oleh beban berat yang diakibatkan oleh adanya penyakit yang akan berpengaruh terhadap produktivitas. Produktivitas individu akan berpengaruh terhadap kegiatan yang dilakukan oleh individu untuk mengahasilkan barang atau jasa, dan dalam jangka panjang hal ini akan berpengruh terhadap kondisi makroekonomi suatu negara. Oleh sebab itu, kebutuhan dasar manusia berupa jaminan kesehatan, jaminan kecelakaan kerja, jaminan kematian, jaminan pensiun, dan jaminan tunjangan hari tua (Janis, 2011) harus dijamin oleh pemerintah, terutama yang berkaitan dengan penjaminan akan kebutuhan kesehatan.

Di berbagai negara khususnya di negara yang sedang berkembang kesadaran masyarakat akan kesehatan terlihat minim. Contohnya adalah di Indonesia, menurut berita dari laman KRJogja.com (2016), menteri kesehatan Republik Indonesia menyatakan bahwa masih banyak masyarakat yang memiliki kesadaran yang rendah terhadap kesehatan. Hanya sekitar kurang dari 20\% dari masyarakat Indonesia yang memiliki kesadaran akan kesehatan. Berangkat dari hal tersebut pemerintah dianggap sangat

\footnotetext{
${ }^{1}$ Input dalam melakukan produksi dalam suatu perekonomian, untuk hal ini adalah sumber daya manusia (SDM)

${ }^{2}$ Atmawikarta, A. (2008). Investasi Kesehatan Untuk Pembangunan Ekonomi. Artikel Bappenas.
}

perlu untuk mengintervensi adanya penjaminan kebutuhan hidup masyarakat, salah satunya dengan memberikan sebuah jaminan kesehatan kepada masyarakat. Hal ini didukung pula oleh adanya deklarasi pada tahun 1978 oleh World Health Organization yang menyatakan bahwa negara-negara anggota berkomitmen terhadap keadilan kesehatan bagi masyarakat, lebih memfokuskan pelayanan kesehatan pencegahan (preventive) dan peningkatan (promotive) dibandingkan dengan pengobatan (currative), dan meningkatkan partisipasi masyarakat dalam meningkatkan kesehatannya.

Sementara itu di Indonesia sendiri, penjaminan kesehatan telah dilakukan sejak terbitnya Undang-Undang Nomor 40 Tahun 2004 tentang Sistem Jaminan Sosial Nasional (Undang-Undang Sistem Jaminan Sosial Nasional yang selanjutnya disingkat UU SJSN) dan Undang-Undang Nomor 24 Tahun 2011 Tentang Badan Penyelenggara Jaminan Sosial (Undang-Undang Badan Penyelenggara Jaminan Sosial yang selanjutnya disingkat UU BPJS). Dengan terbitnya kedua undang-undang tersebut, pemerintah diwajibkan untuk memberikan lima jaminan dasar bagi seluruh masyarakat Indonesia diantaranya : jaminan kesehatan, jaminan kecelakaan kerja, jaminan kematian, jaminan pensiun, dan jaminan tunjangan hari tua Janis, (2011).

Melalui terbitnya UU SJSN dan UU BPJS pemerintah diberikan amanat untuk menjamin kebutuhan atas jaminan dasar bagi setiap masyarakatnya. Dalam hal ini penulis hanya akan membahas mengenai jaminan kesehatan yang dikelola oleh Badan Penyelenggara Jaminan Sosial Kesehatan atau BPJS Kesehatan.

Seperti telah diketahui bersama, bahwa melalui adanya amanat dari Undang-Undang SJSN dan Undang-Undang BPJS pemerintah kini sudah berupaya untuk merealisasikan undang-undang tersebut, dimana dalam rencana pemerintah, seluruh masyarakat Indonesia pada tahun 2019 akan dijamin kesehatannya oleh pemerintah, melalui keikutsertaan dalam BPJS Kesehatan. Tujuan adanya BPJS adalah menjamin agar peserta memperoleh manfaat pemeliharaan kesehatan dan perlindungan dalam memenuhi kebutuhan dasar terutama dalam hal yang berkaitan dengan kesehatan.

Pada tahun 2017, jumlah peserta BPJS sudah mencapai 176.738.998 orang. Dari jumlah penerima jaminan kesehatan tersebut, menurut data dari BPJS sebagian besar peserta BPJS Kesehatan dibiayai oleh pemerintah melalui adanya program Penerima Bantuan Iuran (PBI), 
yaitu sebanyak 99.044.288 orang, dan sisanya dibiayai oleh institusi tempat mereka bekerja dan bayar secara mandiri. Hal ini menandakan bahwa banyak masyarakat yang memiliki penghasilan yang rendah sehingga mereka diberikan bantuan berupa pembiyaan premi iuran BPJS Kesehatan. Dengan kata lain masyarakat yang menerima PBI masih dianggap belum mampu untuk membayar iuran sehingga iuran mereka berupa premi dibayarkan oleh pemerintah. Dari informasi yang dimuat oleh laman Go Aceh, menyebutkan bahwa sebesar $1,3 \%$ peserta BPJS mengalami masalah dalam penyakit berbahaya yang ada di Indonesia. Seperti masalah dalam penyakit jantung koroner, TBC, AIDS, dan kanker.

Dilatar belakangi oleh adanya kasus tersebut, penulis ingin mengetahui seberapa besar pengaruh dari adanya kemiskinan, pengangguran, jumlah penderita penyakit jantung koroner, penderita penyakit TBC, penderita penyakit kanker, dan penderita penyakit AIDS terhadap permintaan jaminan kesehatan melalui keikutsertaan kepada BPJS Kesehatan.

\section{METODOLOGIPENELITIAN}

Objek dalam penelitian ini adalah jumlah penderita penyakit jantung koroner, jumlah penderita penyakit kanker, jumlah penderita penyakit $\mathrm{TBC}$, dan jumlah penderita penyakit AIDS, serta jumlah pengangguran dan penduduk miskin yang ada di Indonesia dengan menggunakan data cross-section, data diambil dari setiap provinsi yang ada di Indonesia selama satu periode, pada periode tahun 2013. Provinsi yang menjadi objek penelitian merupakan provinsi yang berada di Indonesia, yaitu sebanyak 33 provinsi.dari setiap provinsi yang ada di Indonesia selama satu periode, pada periode tahun 2013. Provinsi yang menjadi objek penelitian merupakan provinsi yang ada di Indonesia sebanyak 33 provinsi.

Data yang digunakan merupakan data sekunder yang didapatkan dari website bps.go.id, kemenkes.go.id, bappenas.go.id, depkes.go.id, litbang.depkes.go.id, pusdatin.kemenkes.go.id, dan bpjs-kesehatan.go,id. Data ini merupakan data kuantitatif dan diolah menggunakan software microsoft excel 2010. Metode penelitian yang digunakan adalah metode regresi sederhana dengan pendekatan OLS $^{3}$ (Ordinary

\footnotetext{
${ }^{3}$ OLS atau Ordinary Least Square merupakan salah satu metode dalam analisis regresi berganda untuk mengetahui pengaruh variabel independen terhadap variabel dependen
}

Least Square). Sebelum melakukan uji statistik terhadap hasil yang diperoleh dari pengolahan data yang menggunakan software Stata13, terlebih dahulu dilakukan uji asumsi. Pengujian asumsi dilakukan agar hasil yang diperoleh menggunakan pendekatan OLS (Ordinary Least Square) mampu untuk memenuhi syarat BLUE (Best, Linear, Unbiased, Estimator). Pengujian asumsi tersebut terdiri dari pengujian terhadap masalah multikolinearitas dan heteroskedastisitas.

Hasil dari regresi ini akan digambarkan melalui sebuah model dengan tujuan model ini akan mampu untuk menginterpretasikan pengaruh antara penyakit berbahaya, pengangguran, dan kemiskinan terhadap permintaan BPJS Kesehatan. Model yang digunakan untuk melihat hubungan setiap variabel adalah sebagai berikut :

$$
\begin{gathered}
y_{i}=\beta_{0}+\beta_{1} x_{1}+\beta_{2} X 2_{i}+\beta_{3} X_{3 i}+\beta_{4} X 4_{i}+\beta_{5} X_{5 i}+\beta_{6} X 6_{i} \\
+u_{i}
\end{gathered}
$$

Keterangan :

$y=$ Jumlah peserta BPJS Kesehatan

$\mathrm{x} 1$ = Jumlah penderita penyakit TBC

X2 = Jumlah penderita penyakit AIDS

x3 = Jumlah penderita penyakit jantung koroner

X4 = Jumlah penderita penyakit kanker

X5 = Jumlah penduduk yang menganggur

x6 = Jumlah penduduk miskin

$\mathrm{u}=$ Eror

Sebelum melakukan pemodelan, terlebih dahulu melakukan uji klasik terhadap hasil regresi. Dari hasil uji asumsi, ternyata asumsi multikolinearitas terpenuhi dengan hasil bahwa tidak terdapat multikolinearitas dalam model ini, dan asumsi heteroskedastisitas juga terpenuhi dengan hasil bahwa tidak terdapat masalah heteroskedastisitas. Dari pengujian tersebut menunjukan bahwa model yang digunakan sudah memenuhi syarat OLS yaitu BLUE (Best, Linear, Unbiased, Estimator), kemudian dari hasil regresi dapat dilihat pula bahwa variabel-variabel 
independen ${ }^{4}$ mampu untuk menjelaskan variabel dependen ${ }^{5}$ sebesar 0.9762 . Itu artinya variabel jumlah penderita penyakit jantung koroner, jumlah penderita penyakit TBC, jumlah penderita penyakit, jumlah penderita AIDS, jumlah penduduk miskin, dan jumlah pengangguran mampu untuk menjelaskan permintaan terhadap BPJS Kesehatan yang dipengaruhi oleh penyakit berbahaya, kemiskinan, serta pengangguran sebesar $97,62 \%$ dan $2,38 \%$ dijelaskan oleh variabel lain yang tidak terdapat di dalam model.

\section{HASIL PENELITIAN}

\section{Peserta BPJS Kesehatan}

Jumlah peserta BPJS Kesehatan pada tahun 2017 telah mencapai peserta sebanyak 176.738.998, dimana peserta ini tersebar di berbagai provinsi di Indonesia. Provinsi dengan jumlah peserta BPJS Kesehatan terbesar adalah provinsi Jawa Barat, dengan total peserta BPJS sebanyak 21.994.860 orang, dan terendah berada di Provinsi Kepulauan Bangka Belitung sebanyak 497.588 orang. Data jumlah peserta BPJS digambarkan oleh grafik 1 yang menunjukan jumlah peserta BPJS Kesehatan tiap provinsi di Indonesia.

\section{Penderita Jantung Koroner}

Sebanyak 3.531.071 merupakan penderita penyakit jantung koroner, dimana persebaran penderita penyakit jantung koroner digambarkan oleh grafik 2, yang menunjukan pesebaran penyakit jantung koroner, persebaran penyakit jantung koroner hampir ada di setiap provinsi. Dari grafik 2 dapat dilihat bahwa jumlah penderita penyakit jantung koroner terbanyak berada di provinsi Jawa Barat dengan jumlah 675.576 orang, hal ini menunjukan bahwa jumlah tersebut ada kaitannya dengan data peserta BPJS dimana jumlah terbanyak juga ada di provinsi Jawa Barat, itu artinya hal ini secara kasar dapat dilihat bahwa penyakit jantung koroner berkaitan dengan jumlah peserta BPJS Kesehatan.

\section{Peserta BPJS}

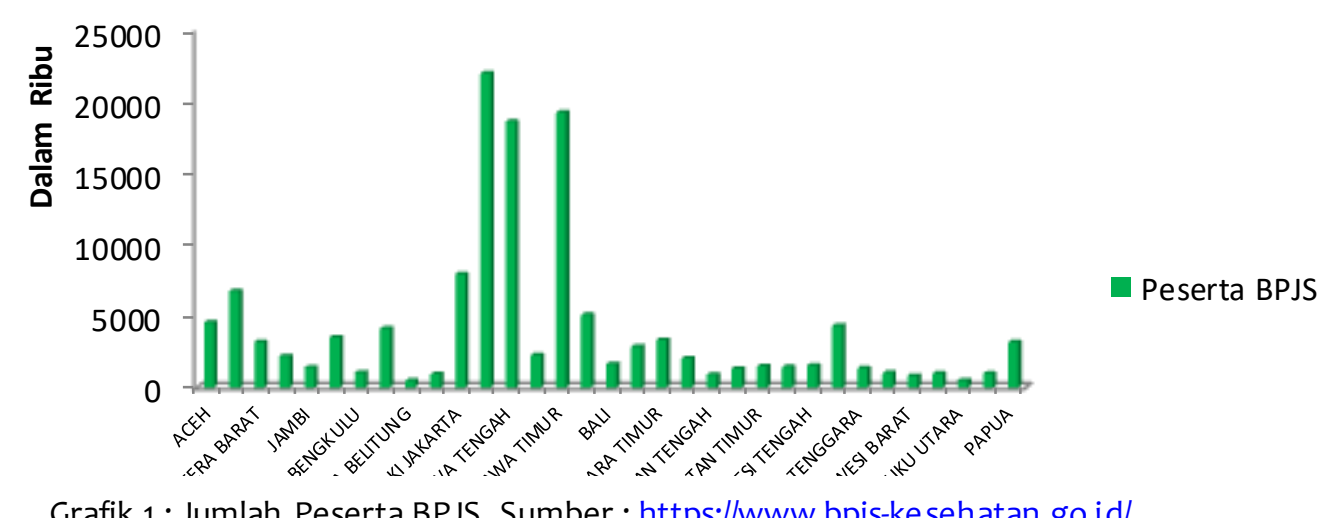

Grafik 1 : Jumlah Peserta BPJS, Sumber : https://www.bpjs-ke sehatan.go.id/

Grafik 1 menunjukan jumlah peserta BPJS Kesehatan di setiap provinsi yanga ada di Indonesia, hampir seluruh provinsi di Indonesia memiliki peserta jaminan kesehatan yang dikelola oleh BPJS Kesehatan.

\footnotetext{
${ }^{4}$ Variabel independen, merupakan variabel yang mempengaruhi variabel dependen

${ }^{5}$ Variabel dependen, merupakan variabel yang dipengaruhi oleh variabel independen
} 


\section{Penderita Jantung Koroner}

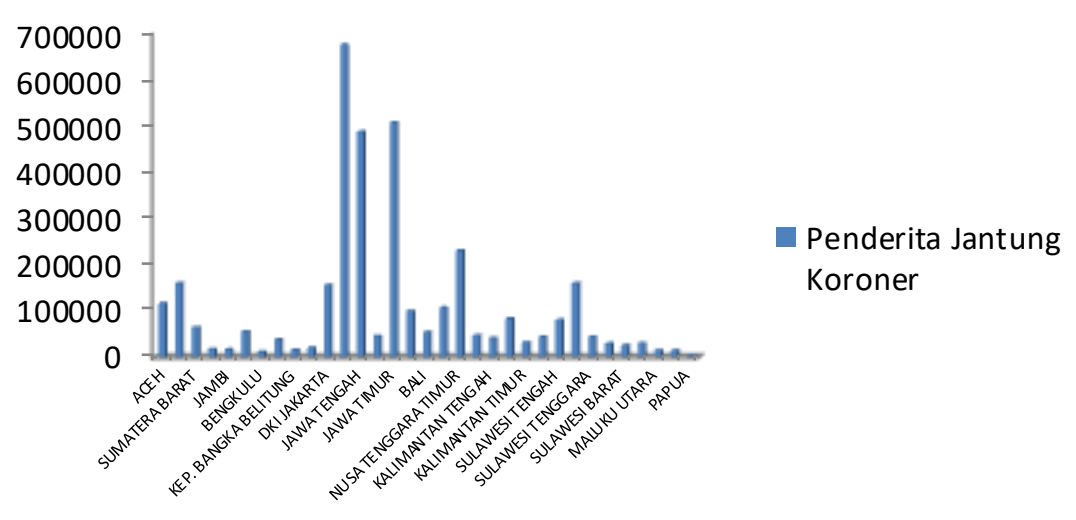

Grafik 2 : Persebaran Jumlah Penderita Penyakit Jantung Koroner, Sumber : Kementerian Kesehatan RI dengan data diolah menggunakan Microsoft Excel (www.kemkes.go.id)

\section{Penderita TBC}

Dari grafik 3 dapat dilihat bahwa persebaran penderita penyakit TBC hampir ada di setiap wilayah, wilayah dengan penderita TBC terbanyak berada di Jawa Barat, dengan jumlah penderita sebanyak 31.469 orang.

\section{Penderita TBC}

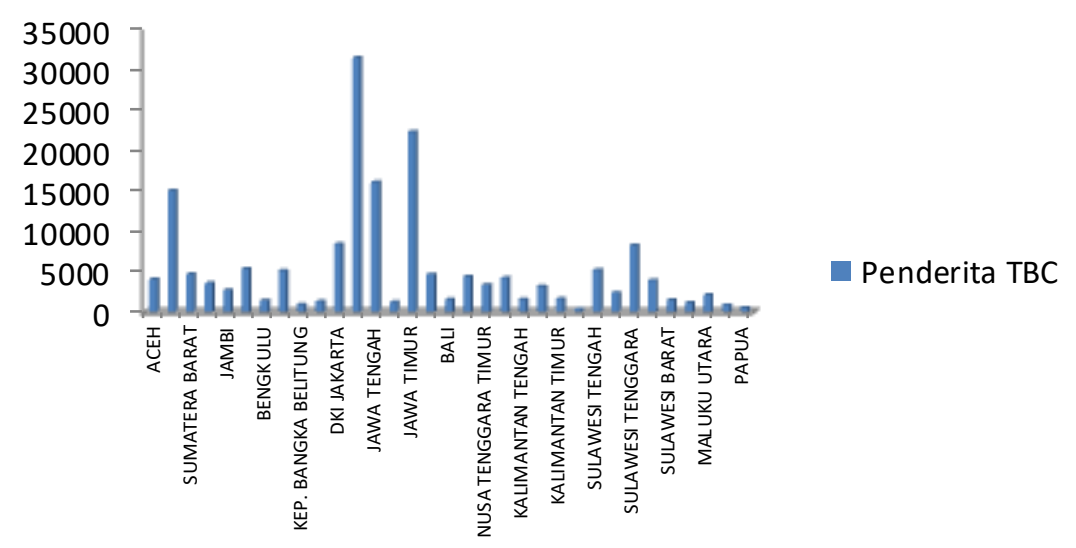

Grafik 3 : Jumlah Penderita Penyakit TBC, Sumber : Kementerian Kesehatan RI dengan data diolah menggunakan Microsoft Excel (www.kemkes.go.id)

\section{Penderita Kanker}

Dari grafik 4 dapat dilihat bahwa persebaran penyakit kanker di Indonesia hampir ada di setiap provinsi di Indonesia, jumlah penderita kanker terbanyak berada di provinsi Jawa Tengah dengan total penderita kanker sebanyak 730.768 orang 


\section{Penderita Kanker}

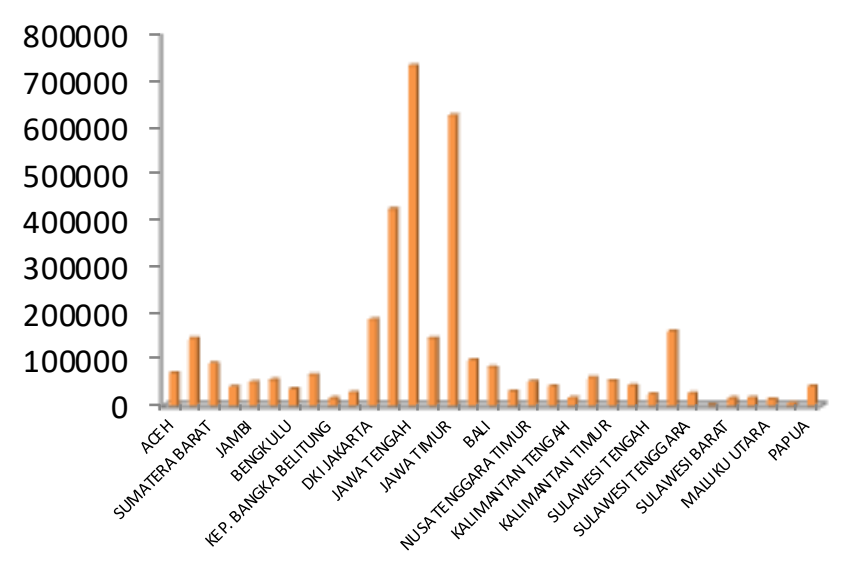

Grafik 4 : Jumlah Penderita Penyakit Kanker, Sumber : Kementerian Kesehatan RI dengan data diolah menggunakan Microsoft Excel (www.kemkes.go.id)

\section{Penderita AIDS}

Dari grafik 5 yang menggambarkan kondisi persebaran penyakit AIDS di Indonesia, dapat dilihat bahwa persebaran AIDS di Indonesia hampir di seluruh wilayah provinsi ada dan jumlah penderita AIDS di Indonesia sebanyak 65.790 orang pada tahun 2013. Dengan jumlah penderita terbanyak berada di provinsi Jawa Timur dengan jumlah penderita sebanyak 12.347 orang, dan disusul oleh provinsi Papua dengan jumlah penderita sebanyak 11.841 orang, dan pada posisi ke-tiga provinsi DKI Jakarta dengan jumlah penderita sebanyak 7.963 orang.

\section{Penderita AIDS}

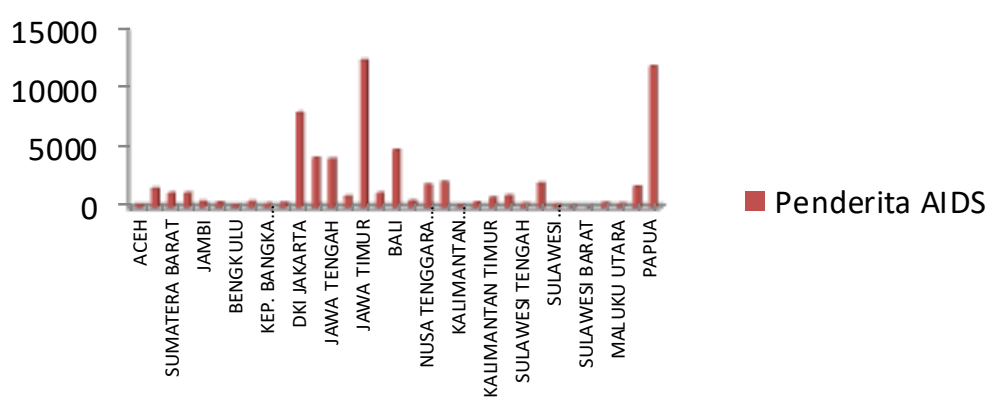

Grafik 5 : Persebaran Penyakit AIDS di Indonesia, Sumber : Sumber : Kementerian Kesehatan RI dengan data diolah menggunakan Microsoft Excel (www.kemkes.go.id)

\section{Jumlah Penduduk Miskin di Indonesia}

Dari grafik 6 dapat dilihat bahwa persebaran jumlah penduduk miskin hampir ada dalam setiap provinsi, provinsi dengan jumlah penduduk miskin terbanyak berada di provinsi Jawa Timur dengan jumlah 4.748.420 penduduk, kemudian di ikuti oleh Jawa Tengah dengan jumlah penduduk miskin sebanyak 4.561.820 penduduk, dan dalam posisi ketiga provinsi Jawa Barat dengan jumlah penduduk miskin sebanyak 4.238.960 penduduk. Total penduduk miskin di Indonesia mencapai 27.727.780 penduduk. 


\section{Jumlah Penduduk Miskin}

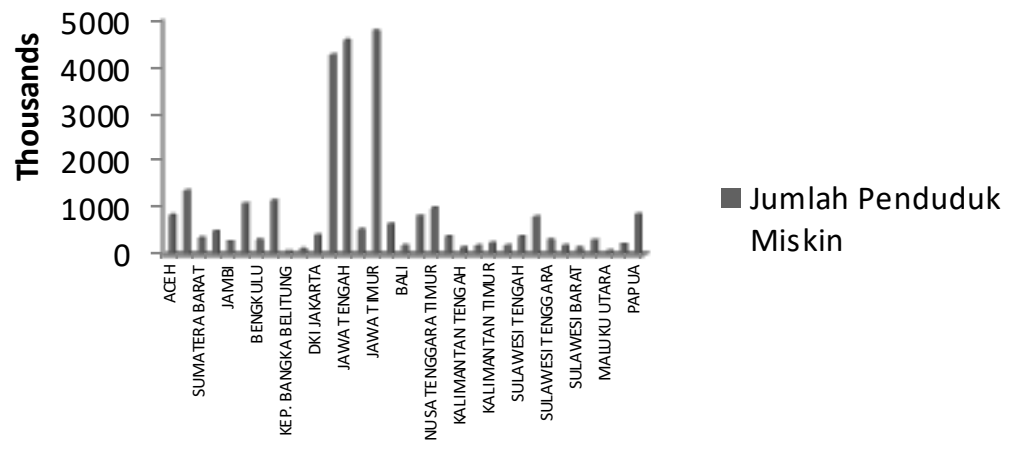

Grafik 6 : Persebaran Penduduk Miskin di Indonesia, Sumber : Badan Pusat Statistik (www.bps.go.id)

Jumlah Pengangguran

Jumlah Pengangguran

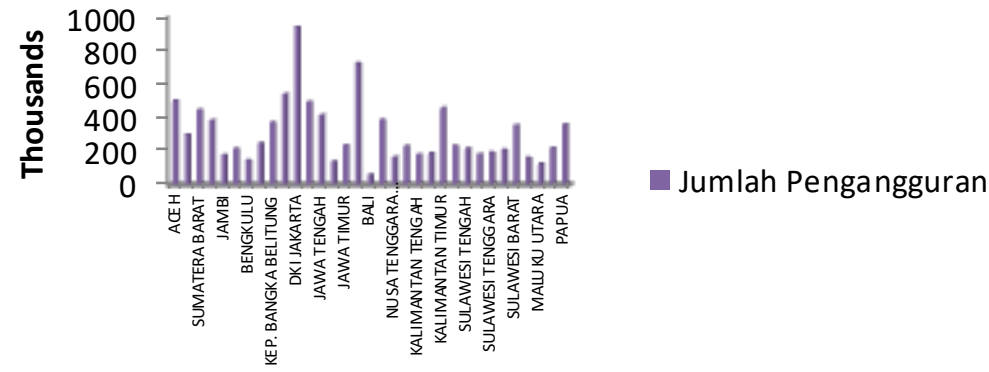

Grafik 7 : Jumlah Pengangguran Setiap Provinsi di Indonesia, Sumber : Badan Pusat Statistik (www.bps.go.id)

Dari grafik 7 dapat dilihat bahwa jumlah pengangguran di setiap provinsi di Indonesia sebagian besar berada di atas angka 1.000.000, dengan jumlah pengangguran tertinggi berada di provinsi DKI Jakarta dengan jumlah pengangguran sebanyak 9.340.000 penduduk, dan kedua berada di provinsi Banten yaitu sebanyak 7.190.000, dan posisi ketiga provinsi Kepulauan Riau dengan jumlah pengangguran sebanyak 5.360.000 penduduk.

\section{Hasil Regresi Menggunakan Stata}

Hasil dari regresi menggunakan Stata menunjukan bahwa semua faktor tersebut (variabel independen : variabel jumlah penderita penyakit jantung koroner, jumlah penderita penyakit kanker, jumlah penderita penyakit TBC, jumlah penderita penyakit AIDS, jumlah pengangguran, dan jumlah penduduk miskin) memiliki pengaruh positif terhadap pergerakan atau pertumbuhan permintaan asuransi kesehatan yang dikelola oleh BPJS Kesehatan. 
http://jurnal.iseibandung.or.id/index.php/ier

Tabel 1 : Hasil Regresi menggunakan Stata 13

\begin{tabular}{l|ccc}
\hline Source & SS & df & MS \\
\hline Model & 29.966911 & 6 & 4.99448516 \\
Residual & .730154031 & 26 & .028082847 \\
\hline Total & 30.697065 & 32 & .959283282 \\
\hline
\end{tabular}

$$
\begin{array}{ll}
\text { Number of obs } & =33 \\
F(6,26) & =177.85 \\
\text { Prob }>F & =0.0000 \\
\text { R-squared } & =0.9762 \\
\text { Adj R-squared } & =0.9707 \\
\text { Root MSE } & =.16758
\end{array}
$$

\begin{tabular}{l|llll}
\hline Ibpjs & Coef. & Std. Err & $\mathrm{t}$ & $\mathrm{p}>|\mathrm{t}|$ \\
\hline Ipdtbc & .0712749 & .0506276 & 1.41 & 0.171 \\
Ipdaids & .1042362 & .0276791 & 3.77 & 0.001 \\
Llpdjankor & .1367202 & .048373 & 2.83 & 0.009 \\
Lpdkanker & .1307204 & .0465803 & 2.81 & 0.009 \\
Lpeng & .2789729 & .0555262 & 5.02 & 0.000 \\
Lpdmiskin & .4815949 & .0511459 & 9.42 & 0.000 \\
_cons & 5.352032 & .4785872 & 11.18 & 0.000 \\
\hline
\end{tabular}

Dari tabel 1 dapat dilihat bahwa masing-masing variabel independen mempengaruhi varibael dependen secara positif dan signifikan, hanya ada satu variabel independen yang tidak begitu

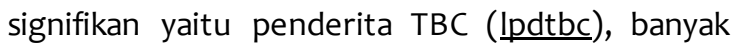
hal yang dapat mempengaruhi variabel independen tersebut tidak signifikan, salah satunya disebabkan oleh adanya ketidak sesuaian data penderita penyakit TBC yang menggunakan biaya pengobatan dengan BPJS Kesehatan.

Hasil tersebut didapat dengan menggunakan logaritma untuk menyederhanakan angka-angka setiap variabel, karena angka-angka dalam variabel tersebut memiliki lima atau enam digit nol di belakangnya, sehingga untuk menyedehanakannya menggunakan logaritma (log). Untuk jumlah peserta BPJS Kesehatan penulis log-kan menjadi variabel lbpjs sebagai variabel dependen, untuk jumlah penderita penyakit TBC penulis log-ka menjadi Ipdtbc, untuk jumlah penderita penyakit AIDS penulis log-kan menjadi Ipdaids, untuk jumlah penderita penyakit jantung koroner penulis log-kan menjadi Ilpdjankor, untuk jumlah penderita penyakit kanker penulis log-kan menjadi Ipdkanker, untuk jumlah penduduk yang menganggur penulis logkan menjadi lpeng, kemudian untuk jumlah penduduk miskin penulis log-kan menjadi Ipdmiskin.

\section{PEMBAHASAN}

Dari tabel 1 dapat dilihat bahwa jika diterapkan ke dalam model ekonometrika yang menggunakan model linear, maka dapat di tuliskan pada persamaan-persamaan berikut :

\section{Persamaan 1: Model Awal}

$$
\begin{aligned}
& y_{i}=\beta_{0}+\beta_{1} x_{i}+\beta_{2} x_{i}+\beta_{3} x_{i}+\beta_{4} x_{i}+\beta_{5} x_{i}+\beta_{6} x_{i}+u_{i} \text {, } \\
& \text { Ibpjs }_{i}=\beta_{0}+\beta_{1} \text { Ipdtbc }_{i}+\beta_{2} \text { Ipdaids }_{i}+\beta_{3} \text { Ilpdjankor }_{i}+ \\
& \beta_{4} \text { Ipdkanker }_{i}+\beta_{5} \text { lpeng }_{i}+\beta_{6} \text { Ipdmiskin }_{i}+ \\
& \mathrm{u}_{\mathrm{i}}
\end{aligned}
$$

Persamaan 2 : Hasil Estimasi

$$
\hat{y}=\hat{\beta}_{0}+\hat{\beta}_{1} X i+\hat{\beta}_{2} X i+\hat{\beta}_{3} X i+\hat{\beta}_{4} X i+\hat{\beta}_{5} X i+\hat{\beta}_{6} X i
$$




\section{Jumlah Peserta BPJS (Ibpjs)}

Dari hasil estimasi regresi persamaan 2 dapat dilihat bahwa apabila jumlah peserta BPJS Kesehatan tidak dipengaruhi oleh variabel apapun jumlah peserta sebesar atau sebanyak 5,352\% dari penduduk Indonesia yang tersebar di setiap provinsi.

\section{Penderita TBC (Ipdtbc)}

Jumlah penderita TBC akan mempengaruhi jumlah peserta BPJS Kesehatan, hubungan antara penderita TBC dan jumlah peserta BPJS Kesehatan berkorelasi positif, akan tetapi tidak memiliki pengaruh yang signifikan. Semakin bertambah jumlah penderita penyakit TBC maka akan menambah jumlah peserta BPJS Kesehatan. Apabila jumlah penderita TBC (Ipdtbc) meningkat sebanyak $1 \%$ maka akan berpengaruh terhadap penambahan jumlah peserta BPJS (Ibpjs) ratarata sebesar $0,0713 \%$, dengan asumsi ceteris paribus. $^{6}$

\section{Jumlah Penderita AIDS (Ipdaids)}

Jumlah penderita AIDS akan mempengaruhi jumlah peserta BPJS Kesehatan, hubungan antara penderita AIDS dan jumlah peserta BPJS Kesehatan berkorelasi positif dan memiliki pengaruh yang signifikan, dengan nilai $\mathrm{p}>|\mathrm{t}|$ 0.001 itu artinya nilai $p$ kurang dari 0.05 maka hal ini menunjukan bahwa variabel Ipdaids tersebut signifikan pengaruhnya terhadap variabel dependen. Semakin bertambah jumlah penderita penyakit AIDS maka akan menambah jumlah peserta BPJS Kesehatan. Apabila jumlah penderita AIDS (Ipdaids) meningkat sebanyak 1\% maka akan berpengaruh terhadap penambahan jumlah peserta BPJS (Ibpjs) rata-rata sebesar 0,1042\%, dengan asumsi ceteris paribus.

\section{Jumlah Penderita Penyakit Jantung Koroner (Ilpdjankor)}

Jumlah penderita jantung koroner akan mempengaruhi jumlah peserta BPJS Kesehatan, hubungan antara penderita jantung koroner dan jumlah peserta BPJS Kesehatan berkorelasi positif dan memiliki pengaruh yang signifikan, dengan nilai $\mathrm{p}>|\mathrm{t}| 0.009$ itu artinya nilai $\mathrm{p}$ kurang dari 0.05 maka hal ini menunjukan bahwa variabel jumlah penderita penyakit jantung koroner (Ilpdjankor) tersebut signifikan pengaruhnya terhadap variabel dependen. Semakin bertambah jumlah penderita penyakit jantung koroner maka akan menambah jumlah

\footnotetext{
${ }^{6}$ Asumsi bahwa variabel lain bersifat tidak berubah atau konstan
}

peserta BPJS Kesehatan. Apabila jumlah penderita jantung koroner (Ilpdjankor) meningkat sebanyak $1 \%$ maka akan berpengaruh terhadap penambahan jumlah peserta BPJS (Ibpjs) rata-rata sebesar $0,137 \%$, dengan asumsi ceteris paribus.

\section{Jumlah Penderita Penyakit Kanker (Ipdkanker)}

Jumlah penderita penyakit kanker akan mempengaruhi jumlah peserta BPJS Kesehatan, hubungan antara jumlah penderita penyakit kanker dan jumlah peserta BPJS Kesehatan berkorelasi positif dan memiliki pengaruh yang signifikan, dengan nilai $\mathrm{p}>|\mathrm{t}| 0.009$ itu artinya nilai p kurang dari 0.05 maka hal ini menunjukan bahwa variabel jumlah penderita penyakit kanker (Ipdkanker) tersebut signifikan pengaruhnya terhadap variabel dependen. Semakin bertambah jumlah penderita penyakit kanker maka akan menambah jumlah peserta BPJS Kesehatan. Apabila jumlah penderita kanker (lpdkanker) meningkat sebanyak 1\% maka akan berpengaruh terhadap penambahan jumlah peserta BPJS (Ibpjs) rata-rata sebesar 0,13072\%, dengan asumsi ceteris paribus.

\section{Jumlah Penduduk yang Menganggur (Ipeng)}

Jumlah penduduk yang menganggur akan mempengaruhi jumlah peserta BPJS Kesehatan, hubungan antara jumlah penduduk yang menganggur dan jumlah peserta BPJS Kesehatan berkorelasi positif dan memiliki pengaruh yang signifikan, dengan nilai $\mathrm{p}>|\mathrm{t}| 0.000$ itu artinya nilai $\mathrm{p}$ kurang dari 0.05 maka hal ini menunjukan bahwa variabel jumlah penduduk yang menganggur (Ipeng) tersebut signifikan pengaruhnya terhadap variabel dependen. Semakin bertambah jumlah penduduk yang menganggur maka akan menambah jumlah peserta BPJS Kesehatan. Apabila jumlah penduduk menganggur (Ipeng) meningkat sebanyak $1 \%$ maka akan berpengaruh terhadap penambahan jumlah peserta BPJS (Ibpjs) ratarata sebesar 0,279\%, dengan asumsi ceteris paribus.

\section{Jumlah Penduduk Miskin (Ipdmiskin)}

Jumlah penduduk miskin akan mempengaruhi jumlah peserta BPJS Kesehatan, hubungan antara jumlah penduduk miskin dan jumlah peserta BPJS Kesehatan berkorelasi positif dan memiliki pengaruh yang signifikan, dengan nilai $p$ $>|\mathrm{t}| 0.000$ itu artinya nilai $\mathrm{p}$ kurang dari 0.05 maka hal ini menunjukan bahwa variabel jumlah penduduk miskin (Ipdmiskin) tersebut signifikan pengaruhnya terhadap variabel dependen. Semakin bertambah jumlah penduduk miskin 
maka akan menambah jumlah peserta BPJS Kesehatan. Apabila jumlah penduduk miskin (Ipdmiskin) meningkat sebanyak 1\% maka akan berpengaruh terhadap penambahan jumlah peserta BPJS (Ibpjs) rata-rata sebesar 0,486\%, dengan asumsi ceteris paribus.

\section{Kesimpulan}

Dari hasil penelitian dan pembahasan mengenai pengaruh penyakit berbahaya, pengangguran, dan kemiskinan terhadap permintan BPJS Kesehatan dapat disimpulkan bahwa variabelvariabel yang digunakan dalam penelitian ini untuk melihat pengaruh penyakit berbahaya, kemiskinan, dan pengangguran terhadap permintaan BPJS Kesehatan mampu untuk menjelaskan hubungan antara variabel dependen dan variabel independen.

Variabel-variabel independen mampu menggambarkan kondisi permintaan terhadap BPJS Kesehatan sebesar 0,9762 atau 97,62\% dan sisanya digambarkan oleh variabel lain diluar model. Pengaruh antara variabel-variabel indenden terhadap variabel dependen memiliki pengaruh yang positif dan masing-masing variabel independen berpengaruh secara signifikan terhadap variabel dependen.

Pengaruh dari adanya peningkatan setiap variabel sebesar $1 \%$, rata-rata pertumbuhan atau pengaruh terhadap permintaan BPJS Kesehatan sebesar kurang dari $1 \%$. Jika variabel dependen tidak dipengaruhi oleh variabel independen apapun jumlah peserta BPJS sebanyak 5,352\% dari penduduk Indonesia.
Pada intinya, penelitian ini menghasilkan kesimpulan akhir bahwa variabel-variabel penyakit jantung koroner, penyakit TBC, penyakit AIDS, penyakit kanker, kemiskinan, dan pengangguran memiliki pengaruh positif terhadap pertumbuhan permintaan BPJS Kesehatan, dengan pengaruh yang signifikan dan berkorelasi positif secara signifikan.

\section{Saran}

Untuk penelitian selanjutnya diharapkan untuk menambahkan variabel penyakit berbahaya lain selain ke empat penyakit berbahaya dalam pembahasan. Kemudian untuk data diharapkan menggunakan data individu, karena dalam penelitian ini menggunakan data makro (agregat) yang merupakan proksi dari setiap variabel. Jika menggunakan variabel dengan menggunakan data individu diharapkan dapat lebih memperjelas hasil penelitian dan mencerminkan keadaan yang sebenarnya. Penggunaan anggaran oleh pemerintah juga hingga saat ini belum efisien (Estro Dariatno Sihaloho, 2018). Dan demikian juga dengan anggaran kesehatan oleh pemerintah juga belum optimal. Dengan demikian dapat dilihat apakah terdapat pengaruh dari efisiensi penggunaan anggaran kesehatan pemerintah terhadap permintaan BPJS. 
http://jurnal.iseibandung.or.id/index.php/ier

\section{DAFTAR PUSTAKA}

Anwar, T. B. (2004). Dislipidemia sebagai faktor resiko penyakit jantung koroner. Fakultas Kedokteran Universitas Sumatra.

Atmarita. (2015). Analisis Situasi Gizi dan Kesehatan Masyarakat.

Atmawikarta, A. (2008). Investasi Kesehatan Untuk Pembangunan Ekonomi. Artikel Bappenas.

BPJS. No Title (2017). Retrieved from www.bpjs.go.id

Fungsi, Tugas, dan Wewenang BPJS. (2016). Retrieved from www.jamsosindonesia.com

Estro Dariatno Sihaloho. (2018). Efficiency Analysis of Local Government Spending of Regencies and Cities in West Java, 2001-2010. Review of Indonesian Economic and Business Studies, 6(2), 111-126. Retrieved from http://jurnalekonomi.lipi.go.id/index.php/riebs/article/view/223

Go Aceh. (2017, February). BPJS Kesehatan : Masyarakat Abaikan 4 Penyakit Kronis Berbahaya.

Janis, N. (2011). BPJS Kesehatan, Supply, dan Demand Terhadap Layanan Kesehatan.

Kementerian Kesehatan RI. (2015). Situasi Penyakit Jantung.

KRJogja.com. (2016, August). Menkes Akui Kesadaran Kesehatan Masyarakat Rendah.

Siregar, A. Y. M., Komarudin, D., Leuwol, B., Afriandi, I., Djuhaeni, H., \& Baltussen, R. (2009). Economic aspect of HIV/AIDS control and injecting drug use in Indonesia. Acta Medica Indonesiana, 41, 70-74.

Todaro, M. P. dan S. C. S. (2011). Pembangunan Ekonomi (Edisi 11 A). Jakarta: PT. Gelora Aksara Pratama.

Widodo, A. (2011). Peningkatan Pembangunan Manusia di Provinsi Jawa Tengah. Jurnal Dinamika Ekonomi Pembangunan, 1, 29. Retrieved from http://ejournal.undip.ac.id/index.php/dinamika_pembangunan/article/view/1656/1430 